\title{
Verbalization of hatred in modern Russian language
}

\author{
Yana Volkova - Olga Dmitrieva - Yekaterina Bobyreva - Nadezhda \\ Panchenko
}

DOI: 10.18355/XL.2018.11.02.14

\begin{abstract}
The aim of this article is to provide a detailed analysis of the linguistic means of verbalization of the Russian emotion concept "hatred". The article considers the results of the analysis that give evidence to the presence of different motivational and emotional bases in the concept structure. The data in the present study came from dictionaries, Russian National Corpus, and a linguistic survey. The methodological approach makes use of conceptual analysis, including conceptual modeling and etymological analysis of the name of the concept, a survey of respondents, which allows clarifying the differential features of the concept, analysis of lexical and phraseological means of its description as well as the corpus of contexts in which the concept reveals itself. The study is based on the semantic-cognitive and discourse approaches towards emotion research.
\end{abstract}

Key words: emotion, emotion concept, emotion word, conceptual metaphor, destructive communication

\section{Introduction}

Aggression and destructiveness are inseparable from people's lives: there is not a single ethnos or society where we do not face aggression in one or another of its forms. To reduce aggressive manifestations at the interpersonal level, it is necessary to understand the nature of aggression and its relationship with other emotional phenomena. Therefore, the study of conceptualization and verbalization of destructive emotions is important not only from the linguistic point of view but also from the universal perspective.

Today the study of emotive language encompasses a variety of issues including linguistic nomination, description and expression of emotions, identification of emotive meanings in the communication process, etc. All of them emphasize the complex nature of human feelings and emotions.

The language of destructive emotions is of particular interest for linguistic research the study of their linguistic representation and, accordingly, conceptualization is a most important stage in the development of the theory of destructive communication. Destructive emotions include a number of hostility group emotions (anger, disgust, contempt) (Izard, 2000), and their conceptual equivalents (irritation, anger, anger, rage, hatred, etc.), as well as emotional-cognitive complexes (for example, revenge, envy, jealousy), which stimulate and support destructive behavior in communication.

The purpose of this article is to analyze the verbalization of emotion "hatred" in the modern Russian language, and to trace changes and modifications in its understanding and evaluation by the society. In fact, we are trying to define how the identified invariant meaning(s) of the lexeme "hatred" (nenavist') correlates with its actualization in discourse and in contexts.

The study uses data from explanatory and etymological dictionaries of the Russian language, examples from the National Corpus of the Russian language (about 3000 units), the Internet discourse and draws on the empirical material obtained from the survey of respondents.

The research is based on semantic-cognitive and discursive approaches to the study of emotions, develops the major points of emotive linguistics and relies on domestic and

XLinguae, Volume 11, Issue 2, April 2018, ISSN 1337-8384, eISSN 2453-711X 
foreign linguistic research (Gevaert, 2007; Kovecses, 1986, 1990, 2005; Lakoff, 1987; Tissari, 2007; Volek, 1987; Wierzbicka, 1999, 2006; Izard, 2000; Vorkachev, 2016; Krasavsky, 2008; Popova \&. Sternin, 2007; Shakhovsky, 2008).

\section{Research Methodology. Emotions in Language}

Apart from general scientific methods, the study makes use of special methods of linguistic research which include a complex method of linguo-conceptual analysis. This method consists of several components: 1) the etymological analysis of the lexeme naming the concept, 2) a linguistic survey which allows us to clarify the distinctive features of the lexical concept under consideration, 3) analysis of the lexical and phraseological means representing the concept in the language, 4) contextual analysis of the corpus of contexts in which the lexeme "hatred" is used.

The term "lexical concept" is widely used in modern linguistics, despite the fact that a single definition of this term has not yet been given. The main provisions of the theory of lexical concepts and approaches to their study and typology are described in detail in numerous studies (Lakoff, 1987; Kovecses, 1986, 1990, 2005, Wierbicka, 1999, 2006; Karasik, 2002; Vorkachyov, 2016; Popova, Sternin, 2010). In the most general sense, the lexical concept in modern linguistics is understood as a complex mental formation, in the structure of which, the cognitive and linguistic sides are intertwined. A good definition was provided by V. Karasik (2002) who defines the lexical concept as a multidimensional mental formation that has figurative, conceptual and value components (Karasik, 2002). Most often the concept is represented in language through the corresponding lexemes, the meanings of which form the naïve picture of the world. V. Karasik's (2002) three-stage model, however, seems insufficient to us when it comes to the conceptualization of emotions. A key lexeme nominating the emotion represents the concept not completely but transmits only a part of its relevant features. In this case, a complete description of the concept involves studying the totality of the language representing it, organized on the basis of the syntagmatic and paradigmatic links of the key lexeme.

Emotion concepts are an extremely difficult object for linguistic research. An average person experiences substantial difficulties trying to speak about emotions: we cannot disagree with the statement that, in the human psyche, it is hardly possible to find a phenomenon more complex, vague, indefinite, and at the same time more significant for personal wellbeing than emotions. Here we find it appropriate to draw a parallel with R. Heinlein's well-known reasoning about the semantic referent of the word "justice", "Examined semantically 'justice' has no referent - there is no observable phenomenon in the space-time-matter continuum to which one can point, and say, 'This is justice.' Science can deal only with that which can be observed and measured. Justice is not such a matter; therefore it can never have the same meaning to one as to another; any 'noises' said about it will only add to confusion" (Heinlein. Coventry. http://dateallaround.com/index.php/article/view/Robert-A.-Heinlein-Coventry). The situation looks absolutely the same with emotions. Indeed, it is difficult to imagine a referent of any particular emotion, for an essential characteristic of human emotions, is their cluster nature. Is it possible to express an emotion, for example, on your face in such a way that the interlocutor could definitely say, "This is anger. It's anger, not fury, not hatred, not extreme irritation "? Is it at all possible to single out the referent of a particular emotion? It is true that non-verbal emotional signs can be assessed objectively. For example, talking about the physiological signs of anger / rage / fury, we can say that the blood pressure rises, body temperature increases, heart rate increases, the accuracy of perception may be impaired (if the emotion is very intense). This is an objective physiological picture of the anger cluster emotions, but it is far from complete. Naive consciousness does not, and should not, have the accurate physiological data for each of the possible emotional states. The objective physiological indices of emotions constitute only the top of the iceberg - a small part 
of the general picture with which each individual cluster of emotions is connected in the human mind.

In the recent past, emotions were often viewed as phenomena that do not have a conceptual content and structure. In this connection, a special approach to the study of emotion concepts in linguistics has been developed. The foundations of the linguistic study of emotions were laid by V.I. Shakhovsky (2008) and his school in the late 80's last century. Since then many followers have shown interest in the study of emotional concepts. Among Russian researchers, it is necessary to mention N. Krasavsky (2008), N.N. Panchenko (2010), Ya.A. Volkova (2014), who have made a significant contribution to the linguistics of emotions.

Let us turn to the existing method of studying lexical concepts: the linguistic study of the lexical concept begins, as a rule, with the semantic analysis of its core lexeme, which, when speaking of emotions, already presents some difficulty. In this section of the paper, we will look at the lexical concept of "gnev" (anger) as a model example of studying lexical emotion concepts. There are several reasons for addressing this concept. First, most aggressive / destructive actions are stimulated by anger and related emotional states (indignation, rage, fury). Anger is included as the basic emotional component - the primary affect - in the structure of such nuclear emotion "compounds" of destructive communication as hatred, envy, and jealousy. Second, anger is among the universal human emotions, the number of which varies, according to different studies, between 5 and 10 (Ekman \& Friesen, 2003; Ekman, 1984, 2014; Izard, 2000). Third, anger has a rich conceptual structure, and its conceptualization is well studied in various languages and cultures (Kövecses, 1986, 1990, 2005; Nikishina, 2006; Pak, 2009; Stefansky, 2008), including our previous studies (Pokrovskaya, 1998). Turning to the semantic analysis of the key lexeme "gnev" (anger) in explanatory dictionaries, we get such definitions as, for example:

(1) Gnev - chuvstvo sil'nogo vozmushhenija, negodovanija (Anger is a feeling of strong indignation, resentment) (Ozhegov, 1990).

(2) Gnev - chuvstvo sil'nogo negodovanija ili vozmushhenija, sostojanie krajnego razdrazhenija ili nedovol'stva kem-l., chem-l. (obychno burno projavljajushheesja) (Anger is a feeling of intense indignation, a state of extreme irritation or displeasure with smb., smth. (usually intensely manifested) (NEWFD).

Such definitions are bad at helping us to understand how the emotion under study is verbalized in language, for one emotional state is defined through another, which in turn requires interpretation. If, on the other hand, we begin to consider the wordssignals of anger or rage, we can get either a series of interjections, traditionally denoting "animal" sounds accompanying human behaviour in anger or rage, or a list of abusive words and expressions reflecting the corresponding emotional state of the speaker. All this vocabulary testifies just to the fact that anger is poorly controlled and provides little data for building its linguo-conceptual picture.

The idea that the study of emotion concepts cannot be reduced to studying the meanings of the words nominating emotions and words expressing emotions was first introduced in the book of Z. Kövecses (1990) "Emotion Concepts" and developed in numerous works on emotive linguistics in Russia and abroad. Speaking about the methodology of emotion concept research, we should note that when analyzing the core of an emotion concept, one should perform not only the semantic analysis of the corresponding lexeme but to include the analysis of metonymical expressions related to internal physiological reactions (physiological manifestations of an emotion stand for the emotion itself) and to involuntary behavioral responses (involuntary nonverbal behavior of a person in anger stands for anger). In the case of anger, the physiological symptoms of this emotion include increased body temperature, increased blood pressure, increased muscular tension, agitation, the impaired accuracy of perception (Kövecses, 1990). It is these "symptoms" that form the basis for the everyday idea of

XLinguae, Volume 11, Issue 2, April 2018, ISSN 1337-8384, eISSN 2453-711X 
anger: knowing this model, we can not only guess that the interlocutor is angry but also simulate this emotion. Using the metonymic principle first used by Z. Kövecses (1990), "the physiological manifestations of emotion stand for the emotion", we described a system of conceptual metonymies of anger in the Russian language, which includes the following metonymies: Redness in the face and neck, agitation and impaired accuracy of perception stand for anger (Pokrovskaya, 1998). It was, however, noted that the individual physiological characteristics of the body can lead not to redness, but, on the contrary, to sharp paleness of the face.

The fact that completely opposite symptoms can indicate the same emotion suggests that, for any emotion (see also the example with fear: (Aitchison, 1995) there are several physiological and behavioral ways, but the language and culture give preference to one of them. For this research, 300 examples of metonymical description of anger in Russian texts were selected. 54\% of examples described anger through reddening in the face and only $12 \%$ of examples - through getting pale. It shows that, in Russian linguoculture, the emotion "gnev" is related to the idea of raised body temperature, blood pressure and, consequently, redness in the face and neck.

The cultural component of emotion concepts is under extensive research at the moment (Components of important meaning 2013; Wierzbicka 1999, 2006.) The studies conducted lead to the understanding that the universal and cultural components of emotion concepts are intricately intertwined. Despite the fact that the biological nature of emotions is universal, each concrete culture chooses its own linguistic ways of their verbalization. A. Wierzbicka (1999) convincingly shows that each language imposes its own classification grid on the emotional experience of people, and consequently, such English words as "anger" or "sadness" are cultural artifacts of the English language. She states that emotions cannot be identified with words, and words belong to one culture and bring with them a culturally specific point of view (Wierzbicka, 1999). Therefore, to answer the question about the correlation between the universal and cultural-specific components of emotion concepts, one should carry out comparative studies on the material of a number of genetically and typologically different languages and cultures.

The next step in describing an emotion concept consists in analyzing its figurative component by selecting, classifying and conducting a semantic analysis of metaphorical expressions used to describe the emotion. Beginning from Aristotle, researchers have always taken interest in the metaphor as a hidden comparison, and at present bibliography on metaphor counts dozens of studies (Apresyan, 1993; Arutyunova, 1990; Vovk, 1986; Gak, 1988; Gudkov, 1994; Ortega, Gasset, 1990; Sklyarevskaya, 1993; Buchowski, 1996; Kövecses, 1986, 1990, 2005; Lakoff \& Johnson, 1980; Lakoff, 1987; Levin, 1993). Such impressive number of works on metaphor confirms R. Hoffmann's words that the metaphor is extremely practical and can be used as an instrument of explanation and description in any field of studies (Arutyunova, 1990).

Using the method of conceptual metaphor in the study of emotion language makes it possible not only to describe and explore the figurative component of the emotion concept but also to clarify such complex abstract models as emotions. For example, comparative studies of the emotional concept "anger" / "gnev" in Russian and English showed that the figurative component of the concept is represented in both languages by similar conceptual metaphors: anger is fire, anger is insanity, anger is a dangerous animal, anger is an enemy (Pokrovskaya, 1998).

It seems interesting that extensive studies of the conceptualization of anger in various unrelated languages (English, Hungarian, Japanese, Zulu, Polish, Chinese, Wolof) have shown that the container metaphor is present in each of them (Kövecses, 2005). This allowed Z. Kövecses (2005) to conclude that this conceptual metaphor is not 
only universal, but, what is especially important, it is inherent in the human being as a biological species (Ibid, 209).

The next step in studying the structure of emotion concepts is to build and analyze the system of cognitive models of the emotion in question, the central one in which is the prototypical scenario of emotion. In the system of cognitive models, prototypes represent the concept as it usually, typically, exists in everyday consciousness, i.e. this is the reproduction of a culturally specific "folk" model of emotion (Kövecses, 1990). As it was already mentioned, emotions present such a complex object for linguistic research precisely because it is impossible to define their prototypes: to say which specific emotion is the prototype of an emotion in general is just as impossible as it is impossible to say what specific feeling of anger, for example, is prototypical for the emotion of anger. According to A. Wierzbicka (1999), a person really interprets his emotional state through such cognitive scenarios, and the lexemes nominating emotions are abbreviated designations of the corresponding prototypical situations. A. Wierzbicka (1999) proposed a method of a scenario construction in the language of semantic primitives, with the help of which many emotional concepts were modeled, including the emotion of "anger" (Ibid, 361). According to Z. Kövecses (1990), the prototypical scenario of anger includes five stages that the anger goes through in its evolution: an abusive action, anger proper, attempts to control the anger, loss of control, and an act of retribution which results in achieving a certain emotional balance and a decrease in the intensity of anger (Kövecses, 1990).

This scenario of anger is obviously not the only one. This is a prototypical scenario, which means that, according to the naive idea of anger, this is a normal development of this emotion. However, the language also captures deviations from the prototype, i.e. the so-called paraprototypical scenarios of the emotion in question. Some varieties of anger in the Russian language were described, among which are "serditost" (gruffness) (the weakest type of anger resulting from any fact that causes discontent), "accumulated anger" (realized in the Russian language through the expressions 'zatait' zlo, derzhat' kamen' za pazukhoy" (to have a grudge against)); "cold anger" (the physiological symptoms of anger are completely or partially absent, and the emotion remains under control); "indignation" (the cause is any insult of moral nature, least of all connected with personal involvement in the situation of communication); "rage, fury" (the strength of the insult is so great that it takes not one but several acts of retribution to restore the disturbed emotional balance). All these situations represent the variation of or deviations from the prototype. Paraprototypical scenarios of anger in Russian also include situations of redirected anger (the offender and the object of aggressive behavior do not coincide), frustrated anger (the act of retribution is impossible for some reason, which brings about a feeling of frustration), a lasting anger (the feeling of anger does not disappear after performing an aggressive action), repressed anger (anger does not result in an aggressive action) (Pokrovskaya, 1998).

The listed paraprototypical scenarios of anger confirm the fact that there is no single cognitive scenario of anger in the Russian language and culture. We can speak about a number of cognitive scenarios with an invariant, prototypical model in the center: varieties of anger are, in this case, the variants of the prototypical scenario.

Studying an emotion concept will not be complete without taking into account the factors that cause a particular emotion. In the case of destructive behavior, these factors are especially important, because they are often used as excuses for aggressive actions. Psychological theories of instinctive and frustrated aggression correspond with our "unscientific," naive ideas of aggression. They justify the idea that aggression occurs as a result of the operation of some instinctive forces that we cannot control completely and which, even attempted to be controlled, can break out under certain conditions. These conditions are very diverse, and most of them (with the

XLinguae, Volume 11, Issue 2, April 2018, ISSN 1337-8384, eISSN 2453-711X 
exception of verbal insults) are non-verbal. They are woven into a general linguoconceptual picture of destructiveness and will not be considered in this paper.

Let us sum up. Emotions are the psychic essence that has always been opposed to logic, so the study of emotional language should be based not on logical but on figurative and schematic knowledge. Despite the fact that when working with emotion concepts in general, we observe the three-step analysis procedure, the linguistic description of emotion concepts has its own specifics. When defining the core meaning component of an emotion word, we propose to consider not only dictionary definitions of the emotion word but to analyze metonymical expressions related to internal physiological reactions (physiological manifestations of an emotion stand for the emotion itself) and related to involuntary behavioral responses (involuntary nonverbal behavior of an angry person metonymically stands for anger). Creating a model emotion concept is carried out according to the following scheme: idioms and fixed expressions (phraseological units) used to describe the emotion under study are grouped into classes of metonymical, metaphorical expressions, i.e, in the so-called conceptual categories (the term by Z. Kövecses, 1990); then the conceptual categories are grouped into cognitive models, or scenarios, among which one, as a rule, is a prototype, and the rest are deviations from the prototype. Thus, it becomes obvious that the linguistic description of emotions becomes the basis for studying emotion concepts.

\section{Results and Discussion}

\subsection{Some General Notes on Hatred}

One of the most striking psychological factors generating any kind of destructive behavior is the emotion of hatred. However, when we hear such phrases as "I hate you," "I hate strong coffee," and "I hate it when animals are treated cruelly," it is not always possible to recognize which emotion is meant. In this section, we'll try to sum up the main modern ideas of hatred.

There could be found several approaches to the study of hatred and defining its role in society. In modern philosophy, an interesting interpretation of hatred as the unity of both a destructive and creative principles belongs to J. Baudrillard (1997). He writes, "We all hate. <...> We all have a dual feeling of nostalgia about the end of the world, in other words, we want to make it final, to give it a purpose, at any cost, even at the cost of bitterness and total rejection of the world as it is. Hatred is mixed with the feeling of an urgent need to speed things up to do away with the system, to free the road for something else, for some event coming from outside. <...> This cold fanaticism contains a millenarian form of challenge and (who knows?) hope". In the modern discourse linguistics, hatred is viewed from the standpoint of the theory of world plurality (Plotnikova, 2008). In psychology, hatred refers to definitely negative emotions, directly stimulating aggressive actions and destroying the personality of the subject. Dislike for a particular individual is a long feeling, which can often turn into hatred. Hatred is not a basic, or primary, affect, such as anger / rage. It is proved that the original function of irritation, anger, and rage is "defending autonomy, removing obstacles or barriers to the desired level of satisfaction, or removing or destroying a source of deep pain or frustration" (Kernberg, 1998). But hatred is the predominant and most complex of affects that form a basis of aggression and destructiveness. Analyzing hatred, a well-known modern psychiatrist and psychoanalyst O. Kernberg (1998) qualifies it as a complex derivative affect, and shows that hatred is not a direct, spontaneous reaction to a stimulus. He states that hatred is a mediated, rationalized, and relatively permanent reaction to an object. The emotional aspect of hatred involves anger / rage as a primary affect: hatred originates from rage and causes the individual to experience rage again and again. The cognitive aspect of hatred includes planning of aggressive actions against the object of hatred up to its physical 
destruction. Recognizing the fact that hatred can be a regular derivative from rage aimed at eliminating a real danger, O. Kernberg (1998) emphasizes that hatred can grow through unconscious motivations invading this natural process and turn into a personality character trait (Kernberg, 1998). The extreme form of hatred requires physical elimination of the object and can find its expression in a murder or suicide. Hatred is revealed in sadistic inclinations, in a passionate desire to dominate the object, in its milder forms - in a cruel attitude towards others and to oneself. There exists pathological hatred, manifested in racial, ethnic, religious hatred, "misanthropy". Thus, O. Kernberg (1998) identifies three aspects of hatred: motivational, emotional and cognitive.

P. Kutter (1998) writes about a type of people suffering from hatred, "There are people who sow discord everywhere, they do not tolerate anyone, they cherish hatred in their hearts. <...> It seems that they are ready to start an irreconcilable dispute without any reason. They not only persist in their hatred, but also embrace it, not taking into account any reasonable arguments. Blinded with rage, they stubbornly pursue the enemy. After they succeed in humiliating him, they immediately turn their anger to someone else" (Kutter, 1998). A brilliant literary example of the description of pathological hatred is Timon of Athens - the legendary misanthrope from William Shakespeare's play. At first Timon declared his love for people, tried to help them, gave generous gifts to friends and strangers, but then went bankrupt and was rejected by those whom he loved and bestowed. In a moment, all Timon's philanthropy turns into burning hatred: he invites guests to a luxuriously decorated table, served with bowls with hot water, and then drives the former friends away, cursing them and finishing his speech with the words, "Burn, house! Sink, Athens! Henceforth hated be of Timon man and all humanity!" (W. Shakespeare. Timon of Athens, Act III, Scene VI. http://shakespeare.mit.edu/timon/full.html). Timon's hate is a reaction to betrayal and insult, it is inexorable, motivated by the desire to avenge the unjust, in Timon's opinion, attitude. Timon leaves Athens and becomes a hermit. It should be noted that the whole fourth act of the play is saturated with such hatred and anger towards everyone and everything that sometimes it is emotionally difficult to read it. Timon calls for chaos and anarchy:

Matrons, turn incontinent!

Obedience fail in children! slaves and fools,

Pluck the grave wrinkled senate from the bench,

And minister in their steads! to general filths

Convert o' the instant, green virginity,

Do 't in your parents' eyes! bankrupts, hold fast;

Rather than render back, out with your knives,

And cut your trusters' throats! bound servants, steal!

Large-handed robbers your grave masters are,

And pill by law. Maid, to thy master's bed;

Thy mistress is o' the brothel! Son of sixteen,

pluck the lined crutch from thy old limping sire,

With it beat out his brains! Piety, and fear,

Religion to the gods, peace, justice, truth,

Domestic awe, night-rest, and neighbourhood,

Instruction, manners, mysteries, and trades,

Degrees, observances, customs, and laws,

Decline to your confounding contraries,

And let confusion live! Plagues, incident to men,

Your potent and infectious fevers heap

On Athens, ripe for stroke! Thou cold sciatica,

Cripple our senators, that their limbs may halt

XLinguae, Volume 11, Issue 2, April 2018, ISSN 1337-8384, eISSN 2453-711X 
As lamely as their manners. Lust and liberty

Creep in the minds and marrows of our youth,

That 'gainst the stream of virtue they may strive,

And drown themselves in riot! Itches, blains,

Sow all the Athenian bosoms; and their crop

Be general leprosy! Breath infect breath,

at their society, as their friendship, may

merely poison! (W. Shakespeare. Timon of Athens, Act IV, Scene 1.

http://shakespeare.mit.edu/timon/full.html)

We quoted Timon's monologue as an example of what uncontrolled, all-consuming hatred can lead to. Needless to say, Timon's communication with people who come to his cave is destructive by nature, for Timon's main communicative goal is to express his hatred and contempt for people, to offend, humiliate them, his farewell words mean to turn their life into hell. Timon does not repent of his actions; he chooses a curse to become his epitaph.

All of the abovestated demonstrates the fundamental role of hatred in the manifestation of destructiveness and interpersonal aggression, in particular. We agree with P. Kutter (1998) that the history of mankind demonstrates our need for hatred, but in fact, it is the object of hatred that really matters. To understand the place of hatred in the conceptual space of destructiveness, it is necessary to consider the structure of the emotion concept of hatred and to find out whether this concept is the only one for the Russian speakers, or there exist several concepts of hatred that are fundamentally different from each other. We can answer this question by analyzing the verbalization of this concept.

\subsection{Verbalisation of Hatred in Russian Linguoculture}

Based on the scheme proposed in the Research Methodology section, we will try to structure the concept of the emotion under analysis.

The explanatory dictionaries of the Russian language offer the following definitions of hatred:

Nenavist' - otvrashcheniye, omerzen'ye; zlozhelatel'stvo, sil'naya nelyubov', vrazhda, zlonamerennost' (Dahl, 1979); chuvstvo sil'neyshey vrazhdy, nepriyazni (BAD); chuvstvo sil'neyshey vrazhdy, zloby (Ozhegov, 1990).

(Hatred - disgust, loathing; malice, strong dislike, enmity, malignancy (Dahl, 1979); a feeling of strong hostility, dislike (BAD); a feeling of extreme hostility, anger (Ozhegov, 1990)).

Thus, we can distinguish the following semantic components of the lexeme "hatred":

1) hatred is a very strong emotion;

2) hatred is cognitively associated with enmity;

3) hatred implies ill wishing to the object;

4) the basis of hatred may be disgust / loathing, i.e. physiological emotions that are not directly related to the notion of anger and enmity.

As can be seen from these definitions, hatred is most often defined through the concept of intensive enmity. And, having looked up the definition of the latter in the same dictionaries, we enter a vicious circle, because enmity is defined as "otnosheniya i deystviya, proniknutyye nepriyazn'yu, nenavist'yu" (Ozhegov, 1990), "nepriyazn', vzaimnaya nenavist', nedobrozhelatel'nyye otnosheniya" (Ushakov, 2000), a nepriyazn' - kak "nedobrozhelatel'nost', nedruzhelyubiye" (Ozhegov, 1990) or "neraspolozheniye, nedobrozhelatel'noye, skryto vrazhdebnoye otnosheniye $\mathrm{k}$ komu/chemu-n." (Ushakov, 2000) ("attitudes and actions imbued with malice, hatred (Ozhegov, 1990),"hostility, mutual hatred, ill-will "(Ushakov, 2000), and dislike - as "ill-will, unfriendliness" (Ozhegov, 1990) or "disposition, unfriendly, covertly hostile attitude to smb. / smth." (Ushakov, 2000). A certain contribution to the fuzzy definition of hatred is made by the etymology of the word: the verb "nenavidet' (to 
hate)" is considered to be derived from "navid"ti", which means "okhotno smotret', naveshchat' (look willingly, visit) (Fasmer, 1996). Thus, it is obvious that, in the Russian language, hatred is treated very broadly: it is, in fact, a hyperonym of "destructive" emotions, beginning with ill-will and ending with disgust and anger. Interestingly, in none of the definitions is hatred defined through anger / rage, although it is clinically proven that it is these emotions (affects) that underlie hatred. But we will return to this question for the further analysis of the semantic core of the concept. Such a broad interpretation of this lexical unit provides equally wide possibilities for its use. Let us turn to examples.

To illustrate this idea, 250 comments of various Internet sites visitors about the objects of their hatred were used as examples. Note that the purpose of some of these sites is to generate catharsis of hatred among visitors. Some comments are just statements of the fact of hatred and its object; others are detailed descriptions of possible motivations and experiences. The range of objects of hatred represented in the selection is amazing: besides such "classical" objects of hatred as mother, motherin-law, father, sister, brother, men, women, injustice, government, the hate sphere includes coffee, sausages, services, lard, cold, dogs, heat, rat tails, rudeness, fat women, children, youngsters, people in transport, impotence, acne, morals, dust, garbage collectors, lack of money, debts, old "Lada" cars, slow Internet, birthdays, New Year, St.Valentine's day. And the list can be continued. A content analysis of these comments allowed us to distinguish three types of motivational bases of hatred: emotional, cognitive and unconscious / nonconscious. The emotional motivation of hatred is represented by such statements as "I hate it because it's disgusting," "I hate men who hate women," etc. In this case, the speaker understands the cause of his hatred and associates it with his negative emotional reaction to the object of hatred. In the case of cognitive motivation, the speaker clearly understands what exactly in the object causes his hatred. This type of motivation is represented by the statements "I hate my husband because he's slovenly," "I hate children because they are always yelling," "I hate my sister because she offends me," etc. In the cases when the motivational basis of hatred is not realized by the speaker himself, one can speak of an unconscious or nonconscious, motivational basis of hatred, "She hasn't done me any harm, but I still hate her." However, it must be remembered that the distinction between these types of motivational bases is rather provisional because the source of hatred (whatever it may be) is always an emotion - the primary affect.

While defining the semantic core of hatred, it is also necessary to take into account the fact that naive consciousness is able to objectively evaluate only the physiological manifestations of the experienced emotional states, and not completely. In the case of "normal" (O. Kernberg's term (1998)) hatred, the objective physiological indicators are increased heart rate, increased heart rate, increased body temperature and blood pressure and, as a result, impaired accuracy of perception. This is what the "emotional person" is able to feel and account for as the physiology of hatred, but these manifestations completely coincide with the physiology of extreme anger, i.e. rage, a detailed analysis of the conceptualization of which was carried out in the previous section. This statement is confirmed by a number of metonymical expressions of hatred, as well as descriptions of the facial expression of hatred. Let us provide a few examples of such descriptions from Russian fiction, in which, as we know, centuriesold ideas about the connection between the external manifestations and the emotions and feelings of the individual are reflected. All the examples are taken from the Russian National Corpus (RNC. http://www.ruscorpora.ru/).

Khotya telo yego drozhalo ot vozbuzhdeniya i nenavisti, on vse zhe staralsya pridat' svoyemu golosu dobrozhelatel'nost', daby ne spugnut' slavista. (Although his body trembled with excitement and hatred, he still tried to give his voice some kindness, so that not to frighten off the slavist. (D. Lipskerov. Forty Years of Changjoe. RNC.)

XLinguae, Volume 11, Issue 2, April 2018, ISSN 1337-8384, eISSN 2453-711X 
Oni smotreli drug na druga, stalkivalis' vzglyadami. I Zheku pryamo tryaslo ot nenavisti. - A vy ne znayete, da?! (They were looking at each other, their glances colliding. And Zheka was shaking with hatred. "Don't you know, don' you?" (E. Shim. The Guys from our Yard. RNC.)

$I$ on $v$ bystroy plyaske pronositsya mimo piruyushchego, i ruki yego drozhat. Bagrovyy tuman nenavisti zastilayet yego glaza. (And he swiftly dashes past the feast, and his hands tremble. The crimson fog of hate covers his eyes. (F. Sologub. Connecting Souls. RNC.)

Takoy zhe shchegolevatyy, stem zhe samodovol'no izvivayushchimsya, bol'shim rtom $i$ $s$ vidom pobeditelya. Katya pokrasnela ot nenavisti. (The same dandy, with the same smug, wriggling, big mouth and with the look of a winner. Katya flushed with hatred. (V. Veresaev. At the Dead End. RNC.)

As you can see, metonymical expressions describing hatred correspond to the following major conceptual metonymies of hatred in the Russian language: REDNESS IN FACE AND NECK ZONES, AGITATION AND INTERFERENCE WITH THE ACCURACY OF PERCEPTION.

A number of metaphorical expressions of hatred, which form the basis of the figurative component of this emotion concept, testify to the fact that hatred is stimulated and heated by the emotions of anger / rage: HATRED AS AN OPPONENT IN STRUGGLE (nenavist' obessilila, isterzala, ovladela; preodolet', odolet', ukrotit', pobedit' nenavist'; neukrotimaya nenavist) (hatred has weakened, torn, possessed, overcome smb.; to tame, overcome hatred; indomitable hatred). Let us illustrate it with some examples from the Russian National Corpus.

Poka nevzrachnyy, vesnushchatyy sekretar', so zvuchnoy familiyey «Karuzo», monotonno, glotaya slova, chital obvinitel'nyy akt, Bolotov ne smotrel na sudey. Nenavist' ovladela im. (While the plain-faced, freckled secretary, with the odd name "Caruso," monotonously swallowing the words, was reading the indictment, Bolotov wasn't looking at the judges. Hatred took hold of him. (B. Savinkov (V. Ropshin). What was not. RNC.)

Terakty $v$ N'yu-Yorke ne pokhoronili demokratiyu, ibo peshchernoy nenavist'yu nevozmozhno pobedit' druguyu peshchernuyu nenavist' $i$ ostat'sya pri etom lyud'mi. (The terrorist attacks in New York did not bury democracy, because it is impossible to defeat one cave hatred by another cave hatred and remain people at the same time. (S. Novoprudsky. One isn't Born to Become Bin Laden. Izvestia, September 12, 2002. RNC.)

YA khochu, no chuvstvo strakha i nenavisti ne mogu preodolet'. (I want to, but the feelings of fear and hatred cannot be overcome.) (V. Shahidzhanyan. 1001 question about THIS. RNC.)

HATRED AS A NATURAL POWER (nenavist' zakhlestyvayet, obvolakivayet) (hatred overflows, enveils, envelops):

Zadvigalis' potnyye muskuly na plechakh Dmitriya Pal'tseva, nenavist', tugaya, kak ruzheynaya pruzhina, obvolakivala telo. (Sweaty muscles on Dmitry Paltsev's shoulders moved, hatred, tough like a rifle spring, enveloped the body. (V. Lipatov, A Village Detective. RNC.)

Yura nikogda ne videl do sikh por, kak slepaya, nerassuzhdayushchaya nenavist' zakhlestyvayet lyudey, i yети ne po sebe stanovilos', kogda on ponimal, chto eto chuvstvo prishlo v povsednevnuyu zhizn' vser'yez i nadolgo. (Yura has never seen till now how blind, unreasoning hatred overflows people, and he felt uncomfortable when he realized that this feeling had come into everyday life seriously and for long. (A. Berseneva. The Age of the Third Love. RNC.)

HATE AS HEAT (nenavist' nakaplivayetsya, raspirayet, vzorvalas'; nenavist' polykhayet, nakalyayet dushu; zhguchaya, goryachaya nenavist'; goryashchiy nenavist'yu (vzglyad); polnyy nenavisti; ogon' / pozhar nenavisti; potushit' nenavist'). (hatred accumulates, bursts, explodes; hatred blazes, it inflames the soul; burning, hot 
hatred, (look) burning with hatred, full of hatred, fire of hatred, put out hatred). The heat accumulates in the vessel (container), causing a constant build-up of pressure, which, eventually, ends up in some kind of explosion (see the container metaphor in Z. Kovesces, 1990):

Nado bylo ukhodit', no on vdrug zakolebalsya: iz yego protivnika bila takaya nenavist', chto on mog ne poyti za nim... (It was necessary to leave, but he suddenly hesitated: there was such hatred flaming in his opponent that he could not follow him ...) (S. Babayan. Rotmistr Nezhentsev. RNC.)

$V$ nem videlos' proyavleniye razzhigayemoy $v$ narode nenavisti $k$ preuspevayushchemu sosedu. (Inside him one could see a manifestation of hatred kindled in the people against a prosperous neighbor.) (O. Volkov, Christmas in Old Petersburg. RNC.)

Viktor tyazhelo dyshal, na sheye vspukhli veny, $v$ rasshirivshikhsya bezumnykh glazakh chernym ognem polykhala nenavist'. (Victor was breathing heavily, his veins were swollen on his neck, his hatred was burning with black fire in his wild eyes.) (E. Volodarsky, Suicider's Diary. RNC.)

A very common perception of hatred is associating it with a wild animal: HATRED AS AN ANIMAL INSIDE A PERSON (lyutaya, zverinaya nenavist') (fierce, bestial hatred):

I voobshche o chem my govorim? On menya nenavidit lyutoy nenavist'yu. On dushem posle menya ne pol'zovalsya! (And in general what are we talking about? He hates me with fierce hatred. He did not use a shower after me! (M. Petrosyan. The House in which ... RNC.)

A potom deti, teper' uzhe zapolnyavshiye vse nemnogoye ostavsheyesya svobodnoye mesto mezhdu gigantskimi tushami stroyeniy, podkhvatili Vanechkin voy, napolnyaya yego zverinoy nenavist'yu $i$ ledenyashchey toskoy, $i$ oni nakonets stali povorachivat'sya $k$ Artemu; $u$ nikh ne bylo lits, tol'ko chernyye kozhanyye maski s vyshcherblennymi rtami $i$ maslyanistymi temnymi sharami glaz bez belkov $i$ zrachkov. (And then the children, now filling in the little remaining space between the giant carcasses of the buildings, seized Vanechka's howl, filling it with bestial hatred and chilling melancholy, and they finally began to turn to Artem; they had no faces, only black leather masks with chipped mouths and oily dark balls of eyes without whites or pupils. (D. Glukhovsky. Metro 2033. RNC.)

HATRED AS A BURDEN (gruz nenavisti, osvobodit'sya ot nenavisti ) (a load of hatred, to unburden oneself from hatred):

Nel'zya skazat', chtoby otets i syn vospylali drug ko drugu lyubov'yu. No gruz nenavisti, skovyvayushchiy Aleshu vsyu zhizn', postepenno rassypàlsya. (One can't say that the father and son have sparked to each other. But the load of hatred, which has been binding Alyosha all his life, was gradually falling apart. (G.Manukyan. I will not Give up without a Fight. RNC.)

Day mne silu osvobodit'sya ot nenavisti $k$ nemu, kotoraya meshayet mne zhit' $v$ kvartire, dushit zloboy, perebivayet mysli... Give me the strength to free myself from hatred for him, which prevents me from living in an apartment, strangles with anger, interferes with my thoughts ... (A. Bobrov. February in the Realm of Darkness. RNC.)

HATRED AS A DISEASE (bolen nenavist'yu, izlechit'sya ot nenavisti, izbavit'sya ot nenavisti ) (sick with hatred, heal from hatred, get rid of hatred):

Glavnomu chuvstvu - nepolnotsennosti, - kotoroye glozhet vsekh, kto bolen nenavist'yu, soobshchestvo oderzhimykh etim chuvstvom predlagayet $i$ drugiye deystvennyye lekarstva. (The main feeling is inferiority, which gnaws all who are sick with hatred, a community obsessed with this feeling offers other effective medications. (V. Havel. Hatred: a Grudge on the Whole World. RNC.)

No pytat'sya spravit'sya s nenavist'yu, izlechit'sya ot neyo - eto nasha obyazannost'. YA govoryu «izlechit'sya», potomu chto v kakom-to rode nenavist' - eto bolezn',

XLinguae, Volume 11, Issue 2, April 2018, ISSN 1337-8384, eISSN 2453-711X 
slovno rakovaya opukhol', pozhirayushchaya nas iznutri. (But to try to cope with hatred, to cure it is our responsibility. I say "cure", because in some way hatred is a disease, like a cancer that devours us from within. (Hatred of hatred. Http://www.myjane.ru/articles/text/?id=1701 (reference date - September 30, 2010.)

Hot hatred is hard to store. Like rage, it is poorly controlled and explodes at the first opportunity. But there is another, "cold" hatred - calm and well-calculated, a detached experience, the main emotion in all types of so-called "cold-blooded" crimes and conflicts. It is this hatred that can be accumulated long and slowly, which is also reflected in a number of metaphorical expressions of hatred: nenavist ${ }^{\prime}$ zrela, leleyat nenavist', vzrashchivat' nenavist' / semena nenavisti (hatred is growing ripe, to cherish hatred / nurture hatred, seeds of hatred):

Mnogiye lyudi leleyut svoyu nenavist', nepreryvno podogrevaya i osvezhaya yeye $v$ pamyati. (Many people cherish their hatred, continuously warming it up and refreshing it in memory.) (Y. Azarov. The Suspect. RNC.)

Ikh tsel' - obostryat' natsional'noye nedovol'stvo, seyat' $\boldsymbol{i}$ vzrashchivat' yadovityye semena nenavisti $k$ Rossii $i$ russkomu narodu. (Their goal is to aggravate national discontent, sow and nurture poisonous seeds of hatred towards Russia and the Russian people.) (Equals of Equality / "Life of Nationalities", June 23, 2000. RNC.)

The ability to conceal, accumulate, cherish hatred, which, in turn, gives the opportunity to plan and carry out acts of revenge, points out to the cognitive aspect of hatred and both conceptually and behaviorally links it with the emotion of contempt and aggression of revenge - a cruel "distant" form of emotional aggression (Fromm, 1994). We believe that the primary effect of "cold" hatred may be either contempt or the so-called "cold fury", when no physiological symptoms of rage can be witnessed. Hatred and contempt often go hand in hand - we have got 180 examples of using these nominations of the emotions by means of the conjunction "and", which indicates that in the minds of native speakers, they act as a kind of emotional cluster.

On sam nenavidel i preziral otvetno lyudey, kotoryye prevratili v posmeshishche yego gore, i potomu yego tleyushchuyu nenavist' k lyudyam vsegda bylo mozhno razdut', dlya svoyey pol'zy - i napravit' na togo ili inogo cheloveka, mesto. (He himself hated and despised those people who turned his grief into a laughing stock, and therefore it was always possible to kindle his smoldering hatred for people for your own benefit and to aim at a particular person. (O. Pavlov. The Steppe Book. RNC.)

I do sikh por, poka ne proizoshlo eto yego pereseleniye $v$ drugoy mir, on nenavidel $i$ preziral Zhorzha, o kotorom pozzhe on stal govorit's kakim-to sniskhoditel'nym prenebrezheniyem... (And until this relocation to the other world had taken place, he hated and despised George, whom he later began to talk about with some indulgent disdain ... (G.Gazdanov. Evelina and her friends. RNC.)

This semantic and conceptual closeness is well illustrated in the aphorism by an unknown French author, "Contempt is hate in a state of rest". Indeed, contempt is a "feeling-attitude", the object of which is a person, a group of persons or a social group. Contempt is caused either by the violation of the basic moral and ethical norms of the society by the object, or by the awareness of the fact that the subject is superior to the object. It seems that contempt is evolutionarily the latest of the hostile emotions, it is a detached experience based primarily on the sense of one's own superiority, on the perception of the object of contempt as a subhuman, which naturally entails hostility and aggression. Evolutionally, this emotion could develop as a means of preparing an individual or a group for an encounter with a dangerous rival, for example, a young man could prepare for a battle through such thoughts as "I am better than my rival, I am stronger than him" (Izard ,2000).

When performing the semantic analysis of the lexeme "contempt", we find the following definition of contempt in the "Dictionary of the Russian language", "gluboko prenebrezhitel'noye otnosheniye k komu-chemu-nibud" ("A deeply disdainful attitude towards anyone") (Ozhegov, 1990). Disdain is defined as 
"vysokomernoye, lishennoye vsyakogo vnimaniya i uvazheniya otnosheniye k komu/chemu-nibud"' ("an arrogant attitude, devoid of all care and respect towards someone / something") (Ozhegov, 1990). The Russian "prenebrezheniye" (disdain) is characterized by a lower intensity of emotional experience than contempt and is associated with personal rather than social norms, i.e. a subjective idea of some individual about the lack of value of an object for that particular subject. Allow us to remind the outward manifestations of contempt: the eyebrows are raised, the face is long, the lips are compressed, the head is lifted, as if the person is looking down upon someone. The contemptuous person seems to be moving away, creating a distance between him and the object of contempt (Izard, 2000). Contempt does not cause any characteristic physiological reactions, psychologically there is a feeling that the subject of contempt is better, higher than the object of emotion, which allows you to look at the object of contempt as something small, insignificant, which gives rise to a general conceptual metaphor GOOD IS UP / BAD IS DOWN, when the object of contempt is considered worse, and therefore below the subject of the emotion (smotret' (glyadet') sverkhu vniz (svysoka) na kogo-libo; smotret' s vysoty svoyego velichiya (look down upon someone, look down one's nose). The metaphorical expressions " ni vo chto ne stavit', "ni v (mednyy) grosh ne stavit" (not to care a doit, to walk all over) reflect the idea that the object of contempt has no value at all. Thus, contempt is a powerful stimulus of destructive behavior and can be a primary effect of "cold hatred." The realization of the fact that you are superior to another, have more rights than another, along with wishing and planning destructive actions, leads to violent crimes, both interpersonal and interethnic.

On the other hand, a number of expressions that name and describe the emotion of hatred make us think that the primary effect of hatred may be neither anger nor contempt, but disgust. If a person hates rat tails, dirty cups, badly washed dishes and other things like that, can one say that the basis of this emotional attitude is rage? It is known that disgust in some aspects is closely related to anger, but has a number of distinctive features. Although disgust in itself is not as dangerous as anger, being associated with anger, it can cause aggression, for anger is an emotion causing a desire to attack, and disgust, in turn, can cause a desire to get rid of the object of the emotion (Izard, 2000). Disgust is one of the most "biological" emotions, evolved from hunger and associated behavior, and originally caused by things that have decomposed in the physical sense (Izard, 2000). In the process of evolution, it spread to things that have decomposed in the psychological sense as well; disgust can refer both to the person, to the idea, and to the very subject of emotion, drastically reducing the self-esteem of the latter. Text examples provide the following synonymic row of the disgust group: otvrashcheniye - omerzeniye - brezglivost (aversion - loathing disgust), and the synonymic dictionary and the Big Academic Dictionary add the lexeme "gadlivost"' (a kind of disgust, no direct equivalent (Ozhegov, 1990). In all vocabulary definitions, the assessment seme "very bad" and the seme "causing nausea" (Ozhegov, 1990) are actualized, which is confirmed by text examples:

Lolita pritvoritsya, chto yeye seychas vyrvet ot otvrashcheniya. (Lolita pretends that she'll now vomit from disgust) ( $V$. Nabokov, Lolita. RNC.)

Yemu omerzitel'na Ameana, ona vyzyvayet u nego brezglivoye otvrashcheniye, potomu chto ona lyubovnitsa pakostnogo Mamurry i potomu chto tam, $v$ spektakle Katulla, na ney bezobraznaya maska - ogromnyy nosishche i glaza, kak u zhaby. Ammeana in detestable to him, she evokes repulsion at him, because she is the mistress of the dirty Mamurra, and because there, in the play of Catullus, there is an ugly mask on her - a huge nose and eyes of a toad's. (V. Osrozhenko. Essays from the book "The Secret History of Creations." RNC.) 
In language, the conceptual link between hatred and disgust is indicated by such expressions as, for example, "brezglivaya nenavist", "toshnit ot nenavisti" (squeamish hatred, suck with hatred) used in some textual descriptions of hatred:

- Svoloch' kakaya! - skazal Oleg s brezglivoy nenavist'yu. - Takikh davit' i davit'... (What a bastard! - Said Oleg with squeamish hatred. - You must kill and kill the ...) (A. Fadeev. The Young Guard. RNC.)

Nas s khudozhnitsey Annoy Os'merkinoy toshnilo ot nenavisti $k$ drugu detstva. (Anna Osmyorkina and I have been feeling sick with hatred to one another since childhood.) (D. Smirnova. A Treacherous Attack of Foods on Man. RNC.)

Thus, hatred in the Russian language can be different - it can be combined with a variety of adjectives: babskaya (womanish), bezgranichnaya (boundless), bezdokazatel'naya (unproven), bezoglyadnaya (reckless), bezotchetnaya (unconscious), bezrassudnaya (reckless), bezuderzhnaya (unrestrained), beskonechnaya (endless), beskrylaya (wingless), besposhchadnaya (ruthless), bessil'naya (powerless), beshenaya (frantic), brezglivaya (squeamish), velikaya (great), gadlivaya (disgusting), glubokaya (deep), glukhaya (deaf), golaya (naked), goryachaya (hot), greshnaya (sinful), dikaya (wild), yedkaya (caustic), zharkaya (broiling), zhguchaya (burning), zhenskaya (female), zhestokaya (cruel), zhivotnaya (animal), zhivuchaya (tenacious), zavistlivaya (envious), zatayennaya (hidden), zverinaya (beastly), instinktivnaya (instinctive), ispepelyayushchaya (sizzling), isstuplennaya (frenzied), ledenyashchaya (freezing), ledyanaya (icy), lyutaya (ferocious), nezasluzhennaya (undeserved), neistovaya (frantic), neistrebimaya (indestructible), neischerpayemaya (inexhaustible), nenasytnaya (insatiable), neprimirimaya (irreconcilable), nerassuzhdayushchaya (unreasoning), neugasimaya (inextinguishable), neukrotimaya (untamable), neutolimaya (slakeless), neutomimaya (indefatigable), nechelovecheskaya (inhuman), ostervenelaya (exasperated), ostraya (acute), otkrovennaya (frank), otkrytaya (open), otchayannaya (desperate), pravednaya (righteous), revnivaya (jealous), r'yanaya (zealous), svirepaya (fierce), svyataya (holy), svyashchennaya (sacred), sil'naya (string), skrytaya (secret), slepaya (blind), slepyashchaya (blinding), smertel'naya (deadly), smertnaya (mortal), smutnaya (vague), spravedlivaya (fair), staraya (old), starinnaya (ancient), strastnaya (passionaqte), strashnaya (terrible), temnaya (dark), tikhaya (quiet), tosklivaya (dreary), tupaya (dull), tyazhelaya (heavy), ubiystvennaya (murderous), udvoyennaya (doubled), upornaya (stubborn), fanaticheskaya (fanatical), kholodnaya (cold), shchemyashchaya (dragging), yadovitaya (oisonous), yaraya (rampant), yarostnaya (furious); zoologicheskaya (zoological), ognennaya (flamy), pervobytnaya (primeval), pylayushchaya (flaming), ekzal'tirovannaya (exalted); vsenarodnaya (nation-wide), vseobshchaya (general), klassovaya (class-specific), narodnaya (public), natsional'naya (national), obshchaya (general), politicheskaya (political), rasovaya (racial), revolyutsionnaya (revolutionary), religioznaya (religious). Based on the dictionary definitions of the phenomenon under study, reflecting the concepts of hatred in naive consciousness, on the analyzed linguistic material and on the results of physiological and psychological research on hatred, we suggest treating hatred as a cluster of negative emotions united by the common name "hatred". Along with anger / rage, the primary effects of hatred may become disgust, contempt, and also some milder "borderline" emotional states (irritation, irritation-disgust, irritation-contempt). This does not necessarily mean that squeamish hatred equals disgust, and contemptuous hatred - contempt. Weaving into an emotional tangle with such emotions as irritation, anger, rage, fury, resentment, malice, they form various conceptual variations of hatred. Thus, we see significant differences in the motivational and emotional aspects of hatred.

With regard to the cognitive aspect of hatred, it includes the planning of aggressive actions against the object of hatred up to its physical destruction (Kernberg, 1998). Most people are familiar with the desire to hurt the object of their hatred (this happens 
regardless of which emotion has "launched" hatred), but since moral and social norms do not allow this, the "revenge plans" either remain unrealized or are translated into more acceptable forms of aggressive actions (including verbal aggression). We will illustrate this statement with some examples from literary texts.

YA byla by blagodarna yey za perekoshennoye nenavist'yu litso, za zhelaniye raskroit' mne cherep, vytsarapat' glaza, unichtozhit' fizicheski. (I would be grateful to her for her face distorted with hatred, for wanting to cut my skull, scratch my eyes, destroy physically. (E. Markova. The Ball. RNC.)

In this example, the subjunctive mood indicates the impracticable plans for the physical destruction of the object of hatred.

Drozha ot nenavisti, voinstvennogo vozbuzhdeniya $i$ nevozmozhnosti stsepit'sya $v$ chestnoy rukopashnoy, protivniki so svoikh pozitsiy polivayut drug druga shkvalom oglushitel'nykh oskorbleniy. (Trembling with hatred, warlike excitement and the impossibility to lock in an honest fistfight, the opponents pour each other with a barrage of deafening insults. (D. Rubina. Me and You under Peach Clouds. RNC.)

In this example, the desired act of physical aggression is replaced by an act of verbal aggression.

The practical material of the research shows that in real communication, hatred is often associated with a feeling of pleasure. To find out concepts associated with "hatred", a free associative experiment was conducted. 100 respondents were asked to give first five associations to the word "hatred". When analyzing the results, it was noted that none of the respondents indicated pleasure or synonymous lexemes in the associative field. In our opinion, this might be explained either by the fact that cultural and ethical norms do not approve of one's receiving pleasure from actions and feelings associated with hatred or respondents may feel uncomfortable, indicating pleasure associated with hatred for the same reason. However, on Internet forums, under the protection of avatars and nicknames, many users admit to their positive feelings and emotions experienced as a result of experiencing hatred (see, for example, the website "Pro nenavist"" ("About Hatred") (http://www.lovehate.ru/Hatred/7), drom.ru, etc.). When conducting an Internet survey, $69.3 \%$ of 65 respondents answered that it was possible to enjoy hatred. According to some respondents, hatred gives "adrenaline, makes stronger", is "an excellent motivator," "boundless, pleasant, intoxicating feeling," "sweet feeling," "brings healing," makes "a brave, normal person," gives "strength to avenge ","meaning to life "," makes a person alive "," singles a person out of the crowd ", to hate "with all your heart is pleasant", it is "worth living for the sake of hatred". Such a positive assessment of hatred and feelings associated with it allows us to define pleasure as a concept related to hatred.

\section{Conclusions}

Having analyzed expressions used in Russian to name and describe the concept of hatred, we can create a prototypical scenario of hatred, which is the final step in analyzing any lexical concept. When building a prototypical scenario of hatred, we faced with the same difficulties as when analyzing the semantic core the emotion concept under study - the inability to determine a single primary affect for hatred. 500 examples of textual description of hatred were analyzed. The results show that, based on the text indicators, $43 \%$ of the examples demonstrate anger / rage / fury as a primary affect; in $16 \%$ of the examples, the emotion that "launched" hatred could not be defined. Based on the data obtained, we can say that the prototypical scenario of hatred is the one where the primary affect is anger / rage / fury:

There is an act offensive to the subject, it is carried out by someone who intentionally, directly or indirectly, insults the subject. The offensive act contains an element of injustice, which causes anger / fury / rage of the subject. To restore justice, an act of

XLinguae, Volume 11, Issue 2, April 2018, ISSN 1337-8384, eISSN 2453-711X 
retribution is required, the strength of which would be equal to the strength of the insult inflicted. However, acts of retribution are dangerous and / or socially / ethically unacceptable, therefore the subject is obliged to restrain his rage. New encounters with the object and new offensive actions on his part take place. The subject again experiences a feeling of anger/ rage, which he has to restrain. The subject has thoughts and images which help him/her plan and visualize an act (s) of retribution, the object of which is the offender. The subject commits an act of retribution, whose strength is approximately equal to the strength of the insult( $(s)$ inflicted, and therefore a certain balance is reached between them. The intensity of hatred falls.

We realize that even in the Russian language and culture, this is by far not the only scenario for the development of hatred. In fact, based on the conclusion drawn about the various possible primary effects of hatred, it can be argued that the only unifying part of all possible hate scenarios will be the emergence of thoughts and images depicting and planning an act of retribution against the object of hatred, for hatred is a powerful factor generating aggression and destructive behavior in communication.

Let us sum up. In the Russian language, the lexemes "nenavist (hatred)", "nenavidet' (to hate)" are widely used to denote and express the cluster of negative emotions, in which, besides the emotions of the anger / rage subcluster, the emotions of the subclusters of disgust, contempt and some others are included, i.e. hatred is conceptually and verbally associated with various aggressive emotions and hostile emotional states. Despite such significant differences in the emotional and motivational components, hatred has a common cognitive component which involves planning of aggressive actions against the object of hatred. The use of the verb "nenavidet' (to hate)" when referred to low intensity emotional states is related both to the semantics of this verb, and to the individual psychological features of the speaking subject. It seems possible that the expression "nenavizhu" (I hate) is cathartic by nature: when the speaker says "I hate" instead of "I don't like", he/she gets rid of the negative emotions that overflow him/her. We also believe that the widespread use of this wordform actualizes the seme of hostility and to some extent neutralizes the powerful aggressive potential of hatred, which does not mean the disappearance or erasing of the basic characteristics of the lexical concept under study.

\section{Acknowledgements}

The publication has been prepared with the support of the "RUDN University Program 5-100".

\section{Bibliographic references}

AITCHISON, J. 1995. Chains, Nets or Boxes? The Linguistic Capture of Love, Anger and Fear. Tübingen: Niemeier. ISBN: 9783484401259

APRESYAN, V.Yu. 1993. Metaphor in the Semantic Representation of Emotions. In: Voprosy Yazykoznaniya, vol. 3, pp. 27-35. ISSN 0373-658X

ARKHIPOVA I.V. 2017. Category of taxis in linguistics (on the basis of German statements with prepositional deverbatives). In: The Novosibirsk State Pedagogical University Bulletin, Vol. 7, No. 4, pp. 196-208, ISSN 2226-3365.

ARUTYUNOVA, N.D. 1990. Metaphor and discourse. Introductory article. In: Theory of metaphor. Moscow: Progress. ISBN 5-01-001599-4

BAUDRILLARD, J. 1997. City and Hatred. Available online: http://www.gumer.info/bogoslov_Buks/Philos/Bodr/Gor_Nas.php.

BUCHOWSKI, M. 1996. Metaphor, Metonymy and Cross-Cultural Translation. In: Semiotica, vol. 110, pp. 301-340. ISSN 1613-3692.

COMPONENTS OF EMOTIONAL MEANING. 2013. A Sourcebook. Oxford: Oxford University Press. ISBN: 9780199592746 
DAHL, V.I. 1979. Explanatory Dictionary of the Living Great Russian language. Moscow: Russian language. ISBN: 978-5-88337-448-6

EKMAN, P. 1984. Expression and the Nature of Emotion. New York: AbeBooks. ISBN 0898593506.

EKMAN, P. - FRIESEN, W. 2003. Unmasking the Face: a Guide to Recognizing Emotions from Facial Expressions. New York: Malor Books. ISBN-10: 1883536367.

EKMAN, P. 2014. Moving toward Global Compassion. St. Petersburg: Peter. ISBN: 978-0991563609

FASMER, M. 1996. Etymological Dictionary of the Russian Language: St.Petersburg: Terra-Azbuka. ISBN: 5-7684-0020-6

FROMM, E. 1994. The Anatomy of Human Destructiveness. Moscow: Respublika. ISBN 5-250-02472-6

GAK, V.G. 1988. Metaphor: universal and specific. In: Metaphor in language and text. Moscow-St. Petersburg. ISBN 5020108898, 9785020108899

GEVAERT, C. 2007. The History of Anger: The lexical Field of Anger from Old to Early Modern English (Unpublished doctoral dissertation). University of Leuven, Belgium. Retrieved from: https://lirias.kuleuven.be/ bitstream/1979/893/2/thesisgedrukt.

GUDKOV, L.D. 1994. Metaphor and rationality. Moscow: Rusina. ISBN 5-73430007-1

IZARD, K. 2000. The Psychology of Emotions. Saint Petersburg: Piter. ISBN 5-31400067-9.

KARASIK, V.I. 2002. Language circle: personality, concept, discourse. Moscow: Gnozis. ISBN 5-7333-0143-0

KERNBERG, O. 1998. Aggression in personality disorders and perversions. Moscow: Independent firm "Klass". ISBN 5863751037

KÖVECSES, Z. 1986. Metaphors of Anger, Pride and Love: A lexical approach to the structure of concepts. Amsterdam: John Benjamins Publishing Company. ISBN 9027225583.

KÖVECSES, Z. 1990. Emotion Concepts. New York: Springer-Verlag. ISBN 1461233127.

KÖVECSES, Z. 2005. Metaphor in Culture: Universality and Variation. Cambridge University Press. ISBN 1139444611.

KRASAVSKY, N.A. 2008. Emotional Concepts in the German and Russian Linguocultures. Moscow: Gnozis. ISBN 978-5-94244-018-3

KUTTER, P. 1998. Love, hatred, envy, jealousy. Psychoanalysis of passions. St. Petersburg: BSK. ISBN 5-9550-0438-6

LAKOFF, G. 1987. Women, Fire, and Dangerous Things. What Categories Reveal about the Mind. Chicago-London: The Univ. of Chicago Press. ISBN: 9780226468044

LAKOFF, G. - JOHNSON, M. 1980. Metaphors We Live By. London: The Univ. of Chicago Press. ISBN: 978-0226468013

LEVIN, S. R. 1993. Poetry, Knowledge, and Metaphor. In: Knowledge and Language, vol. 3, pp. 81-93. ISBN: 978-94-011-1844-6

NIKISHINA, I.V. 2006. Expression of the concept "anger" in English fiction. In: Language. Consciousness. Communication. Moscow: MAX Press. ISBN: 5-31701694-0

ORTEGA, Y. - GASSET, H. 1990. Two great metaphors. In: Theory of metaphor. Moscow: Progress, pp. 68-81. ISBN 5-01-001599-4

OZHEGOV, S.I. 1990. Dictionary of the Russian language. Moscow: Russkiy Yazyk. ISBN 5-200-01088-8

PAK, E.V. 2009. The etymology of the concept "anger" in English. In: Izvestiya RSPU named after A.I. Herzen, vol. 9, pp. 215-218. ISSN 1992-6464 
PANCHENKO, N.N. 2010. Authenticity as a communicative category. Volgograd: Peremena. ISBN: 978-5-9935-0153-6

PLOTNIKOVA, S.N. 2008. Struggle against identity: hatred in the light of the theory of plurality of worlds. In: Ethnosemiometry of value meanings. Irkutsk: IGLU. ISBN 978-5-88267-285-9

POKROVSKAYA, Ya.A. 1998. Reflection in the language of the aggressive states of the person: Doctoral dissertation. Volgograd.

POPOVA, Z.D. - STERNIN, I.A. 2010. Cognitive Linguistics. AST, Vostok-Zapad. ISBN. 978-5-17-045103-6.

SHAKHOVSKY, V.I. 2008. Linguistic Theory of Emotions. Moscow: Gnozis. ISBN 978-5-94244-019-0

SKLYAREVSKAYA, G.N. 1993. Metaphor in the system of language. St. Petersburg: Piter. ISBN: 5-02-028138-7

STEFANSKY, E.E. 2008. Emotional concepts as a fragment of mythological and modern language pictures of the world. Samara: Samar. ISBN 978-5-98996-074-3

TISSARI, H. 2007. Current Emotion Research in English Linguistics: Words for Emotions in the History of English. In: Emotion Review, vol. 9, n.1, pp. 86-94. ISSN: 1754-0739

USHAKOV, D.N. 2000. Explanatory Dictionary of the Russian Language. Moscow: Publishing house AST. ISBN 5-17-000477-X

VOLEK, B. 1987. Emotive Signs in Language and Semantic Functioning of Derived Nouns in Russian. Amsterdam: Benjamins. ISBN 9789027215291

VOLKOVA, YA.A. 2014. Destructive communication in cognitive and discursive aspects. Volgograd: Peremena. ISBN 978-5-9935-0326-4

VORKACHYOV, S.G. 2016 Ex Pluribus Unum: Linguocultural Concept as a Synthesis Formation. In: Russian Journal of Linguistics. Vestnik RUDN, vol. 2, 17-30. ISSN: 2312-9182

VOVK, N.N. 1986. Language metaphor in colloquial speech. Kiev: Naukova Dumka. ISBN: 3-55159-971-7

WIERZBICKA, A. 1999. Emotions across languages and cultures: Diversity and Universals. Cambridge: Cambridge University Press. ISBN 0521599717.

WIERZBICKA, A. 2006. English: Meaning and Culture. Oxford: Oxford University Press. ISBN 0198038976.

Words: 10409

Characters: 69512 (38,62 standard pages)

Prof. Yana Volkova, Dr.of Philology

Department of Foreign Languages

Peoples‘ Friendship University of Russia, RUDN University

6 Miklukho-Maklay Str., Moscow

Russia

volkova_yaa@pfur.ru

Prof. Olga Dmitrieva, Dr. of Philology

Department of Russian as a Foreign Language of the Faculty for the Training of

Foreign Citizens

Volgograd Social Pedagogical University

27 Lenin Av., Volgograd

Russia

dmoa@yandex.ru

Prof. Yekaterina Bobyreva, Dr. of Philology

Department of Foreign Languages 
Volgograd Social Pedagogical University

27 Lenin Av., Volgograd

Russia

new_life@mail.ru

Prof. Nadezhda Panchenko, Dr. of Philology

Department of Foreign Languages

Volgograd Social Pedagogical University

27 Lenin Av., Volgograd

Russia

panchnn@yandex.ru 